\title{
ATYPICAL PRESENTATIONS OF TUBERCULOSIS
}

\section{S. Ramanathan ${ }^{1}$, M. Vidhya Sagar ${ }^{2}$}

${ }^{1}$ Associate Professor, Department of Orthopaedics, Thanjavur Medical College, Thanjavur.

${ }^{2}$ Consultant Orthopaedic Surgeon, Chennai.

HOW TO CITE THIS ARTICLE: Ramanathan S, Sagar MV. Atypical presentations of tuberculosis. J. Evolution Med. Dent. Sci. 2017;6(63):4624-4629, DOI: 10.14260/Jemds/2017/1000

\section{PRESENTATION OF CASE}

Here, we describe 2 cases of atypical presentations of Osteoarticular Tuberculosis.

\section{Case I}

We describe a 12-year-old girl with right hand dominance, who came with complaints of pain and swelling over Lt. forearm for 4 months. Swelling was initially small, gradually progressive; Pain was present only on hard work. There was no other specific positive history.

On examination there was diffuse swelling over the Lt. forearm, mild tenderness, no warmth, more on radial side, no scars/sinuses. The Range of Motion was full (Elbow and Wrist).

\section{$X$-Ray Lt. Forearm (AP and Lateral Views)}

Osteolytic lesion in Diaphysis and metaphysis.
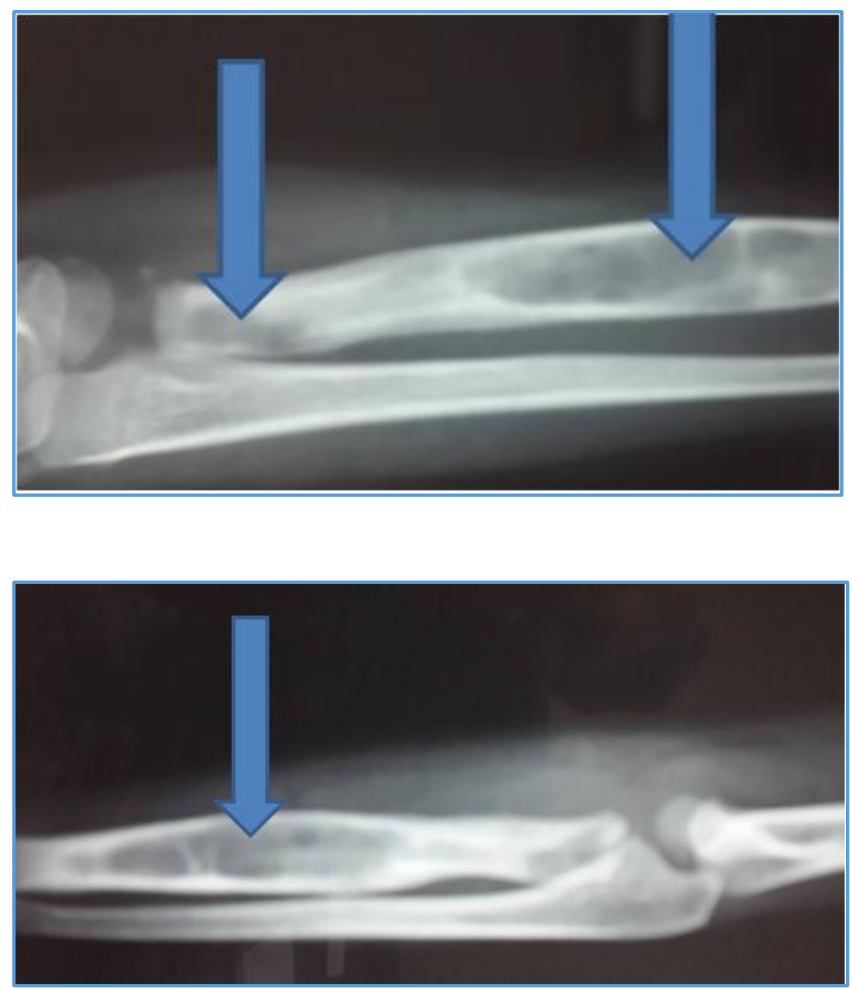

Financial or Other, Competing Interest: None.

Submission 03-07-2017, Peer Review 28-07-2017,

Acceptance 02-08-2017, Published 07-08-2017.

Corresponding Author:

Dr. M. Vidhya Sagar,

No.4/2, Lakshmipuram $2^{\text {nd }}$ Street,

New-Avadi Road, Villivakkam,

Chennai- 600049.

E-mail: vidhyasagarm@hotmail.com

DOI: $10.14260 /$ jemds/2017/1000

\section{(c) (1) $(9)$}

Clinical Picture- Minimal Swelling with Ill-Defined Borders
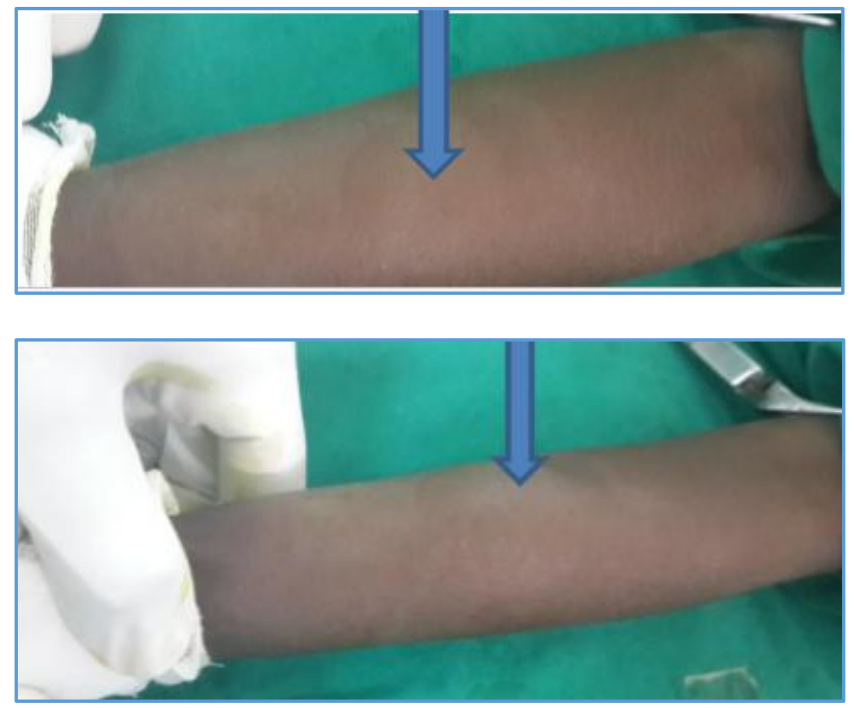

MRI Imaging
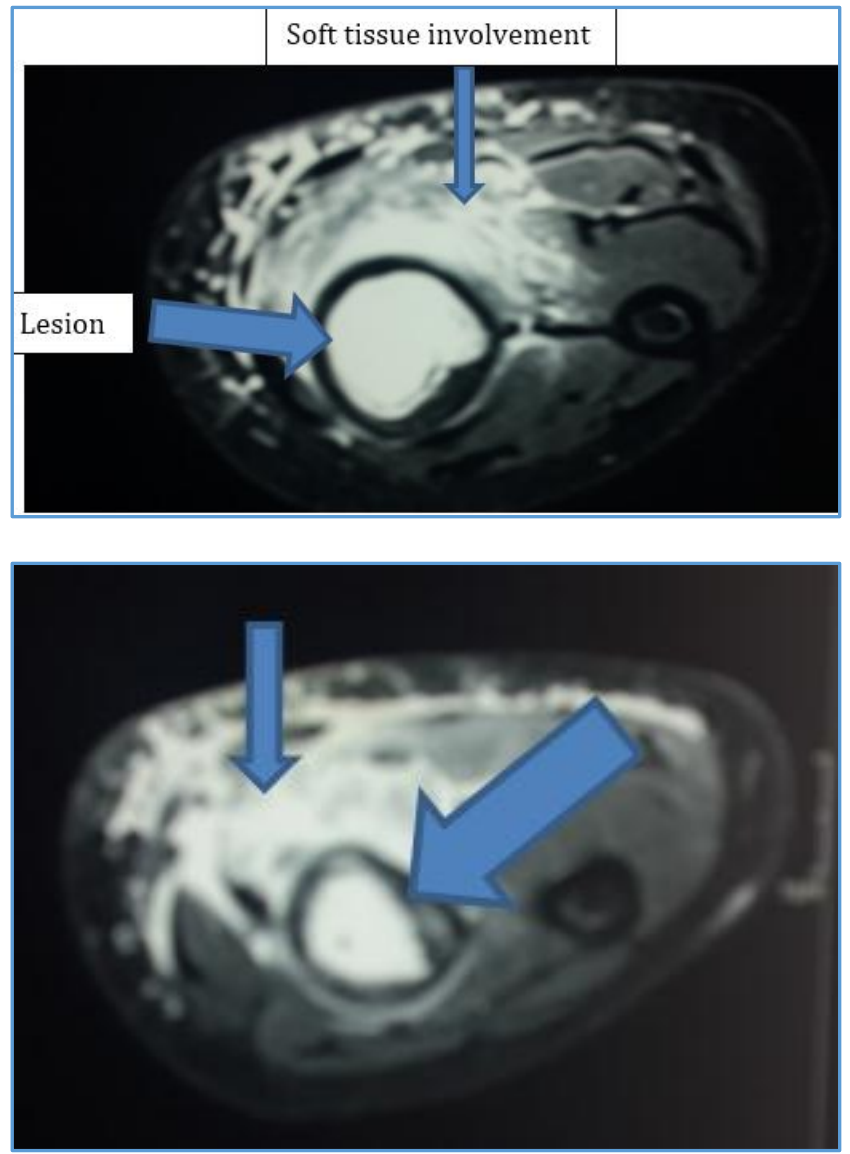


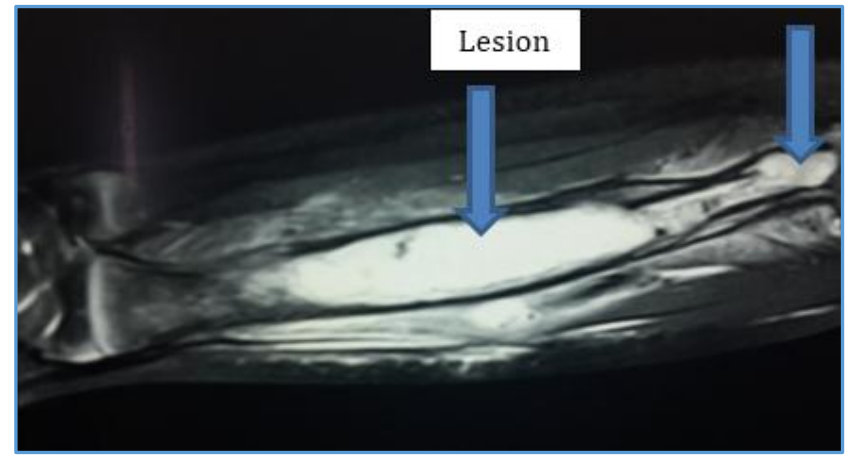

Other Investigations Done Were

- TC, DC.

- ESR: $30 \mathrm{~mm} / \mathrm{hr}$.; CRP negative.

- CXR: Normal.

- Mantoux Test: Negative.

- MRI Report: Hypodense? Subacute Osteomyelitis (? TB, ? Infective) correlate clinically, adjacent soft tissue involved.

The patient was initially thought to be having a subacute osteomyelitis or a benign tumour. It was proceeded with Open Biopsy.

\section{Case II}

We describe a 54-year-old female with right hand dominance, came with complaints of pain and swelling over the Lt. knee for the past 6 months. It was gradually progressive, inc. on hard work and squatting. No h/o fever, chronic cough, LOW, LOA, evening rise in temp., night cries, night sweats or TB contact.

On examination there was swelling and tenderness over the Lt. knee, more on medial aspect. Synovial thickening was present. There was no warmth/ scars/ sinus/ patellar tap/ crepitus/ deformity.

Range of Motion was full, but minimal pain on extremes of motion.

\section{X-Ray Left Knee Joint (AP and Lateral Views)}

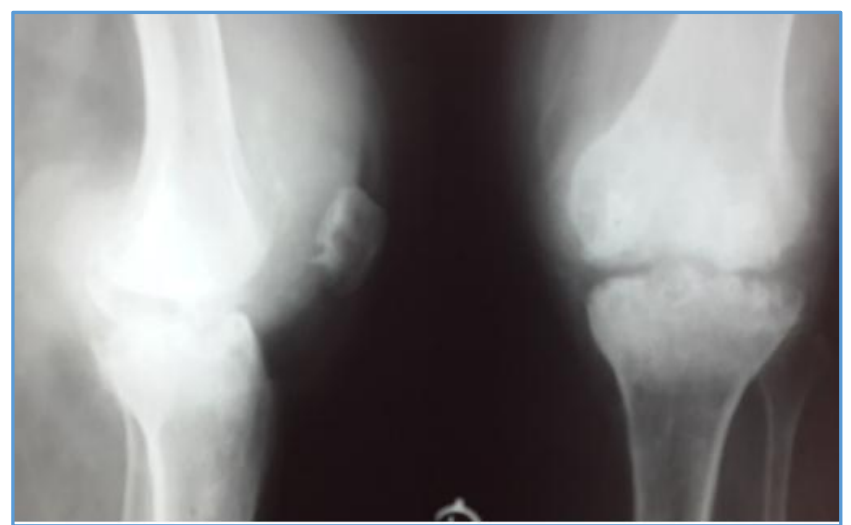

Patient was a known case of Type II Diabetes Mellitus, on treatment. Clinically and Radiographically Neuropathic or an Osteoarthritic Joint.

\section{Other Investigations Were Done}

- TC, DC- Normal; Blood Sugar Elevated.

- ESR- $30 \mathrm{~mm} / \mathrm{hr}$.; CRP: Negative.

- CXR- Normal.
- Synovial Fluid Analysis- Proteins increased; Sugar reduced.

- Mantoux- Negative.

Finally, the patient was planned for Synovial Biopsy.

\section{DIFFERENTIAL DIAGNOSIS}

For Case 1

- Subacute Osteomyelitis.

- Benign Tumour.

For Case 2

- Charcot Joint.

- Rheumatoid Arthritis.

- Osteoarthritis.

- Low Grade Septic Arthritis.

\section{CLINICAL DIAGNOSIS}

For Case 1

- Subacute Osteomyelitis.

\section{For Case 2}

- Charcot Joint.

\section{PATHOLOGICAL DISCUSSION}

\section{Introduction and History of Tuberculosis}

TB was known to humans even 5,000 years ago. In India, it was described in Rigveda and Atharvaveda[1] (3500 - 1800 BC) "Yakshma." ТВ lesions have been described long ago in Egyptian Mummies.[2] Hippocrates described Pulmonary Tuberculosis in the year 400 BC.[3] The TB epidemic in Europe, also called as the "Great White Plague," rooted in the beginning of the 17 th century.[4]

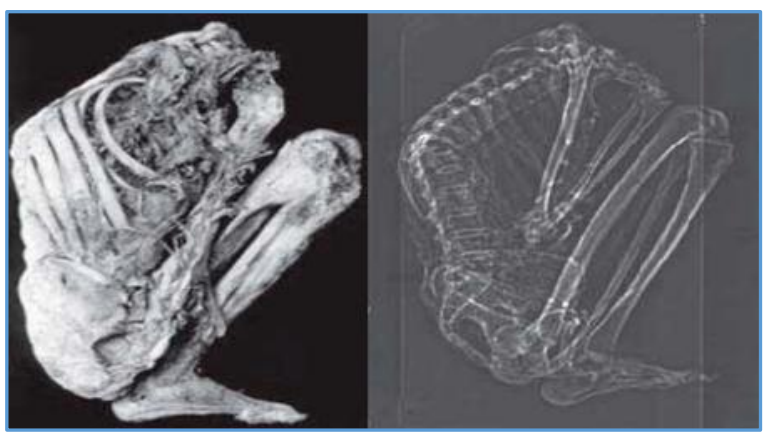

MUMMY OF A TB SPINE AND CT SHOWING LESION T10/T11

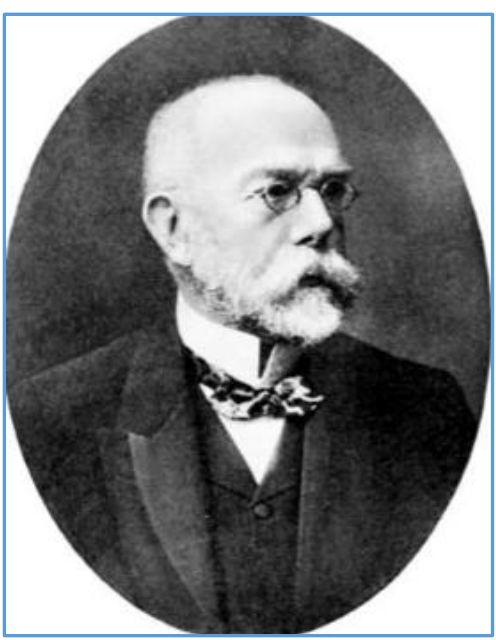




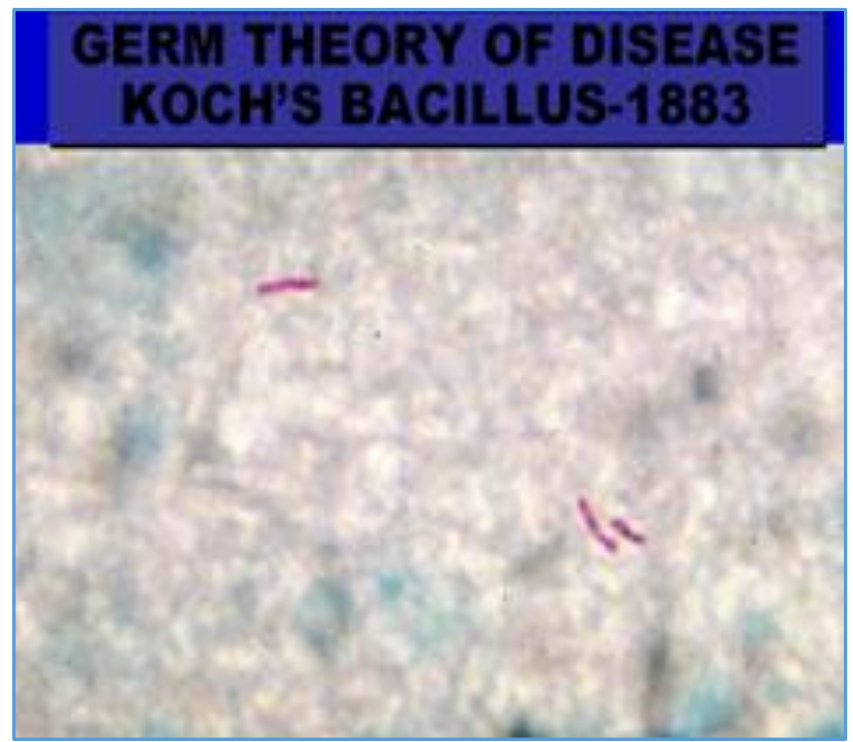

Robert Koch discovered Mycobacterium tuberculosis, the causative agent in the year 1882.[5]

$\begin{array}{lc}\begin{array}{l}\text { DISTRIBUTION OF TUBERCULOSIS INVOLVEMENT } \\ \text { Site of Involvement }\end{array} & \begin{array}{c}\text { Percentage } \\ \text { Pulmonary tuberculosis }\end{array} \\ \text { Extrapulmonary tuberculosis } & 14 \\ \text { Lymphatic } & 27 \\ \text { Pleural } & 21 \\ \text { Genitourinary } & 16 \\ \text { Milliary } & 9 \\ \text { T Bone and Joint } & 8 \\ \text { Meningeal } & 4 \\ \text { Peritoneal } & 4 \\ \text { Others } & 1\end{array}$

\section{INVESTIGATIONS}

- AFB Staining.

- HPE.

- Mantoux Test.

- Culture- LJ and BACTEC.

- ELLISPOT- IgM and IgG Antibodies.

- PCR.

- Interferon Assays- TB antigens ESAT-6 and CFP-10.

- ADA assay.

- Imaging Modalities.

\section{DRUGS IN MANAGEMENT}

$1^{\text {ST }}$ Line

- Isoniazid.

- Rifampicin.

- Pyrazinamide.

- Ethambutol.

$2^{N D}$ Line

- Ethionamide.

- Kanamycin.

- Pas.

- Amikacin.

- Cycloserine.

- Ofloxacin.

\section{Atypical Presentations}

- Unusual Presentations: Persistent backache, referred pain to trunk, abdomen, present as spinal tumour syndrome, ankylosing.[6]

- Spondylitis.[7]

- Evidences of associated extraskeletal tuberculosis like cough, expectoration, lymphadenopathy, diarrhoea and abdominal distension may be seen.[8]

\section{DISCUSSION OF MANAGEMENT}

\section{Case I}

The patient was initially thought to be having a subacute osteomyelitis or a benign tumour. It was proceeded with Open Biopsy.

\section{Surgical Procedure}

Open Biopsy and Curettage was done for this patient.

Per-operatively, the cavity was filled with pus and caseous material.

The various investigations that were done after the procedure-

- Pus Culture and Sensitivity- no growth.

- HPE (Granulation Tissue)- Tuberculous Granuloma.

- Cat-I ATT was started.

\section{Per-Op Pictures}
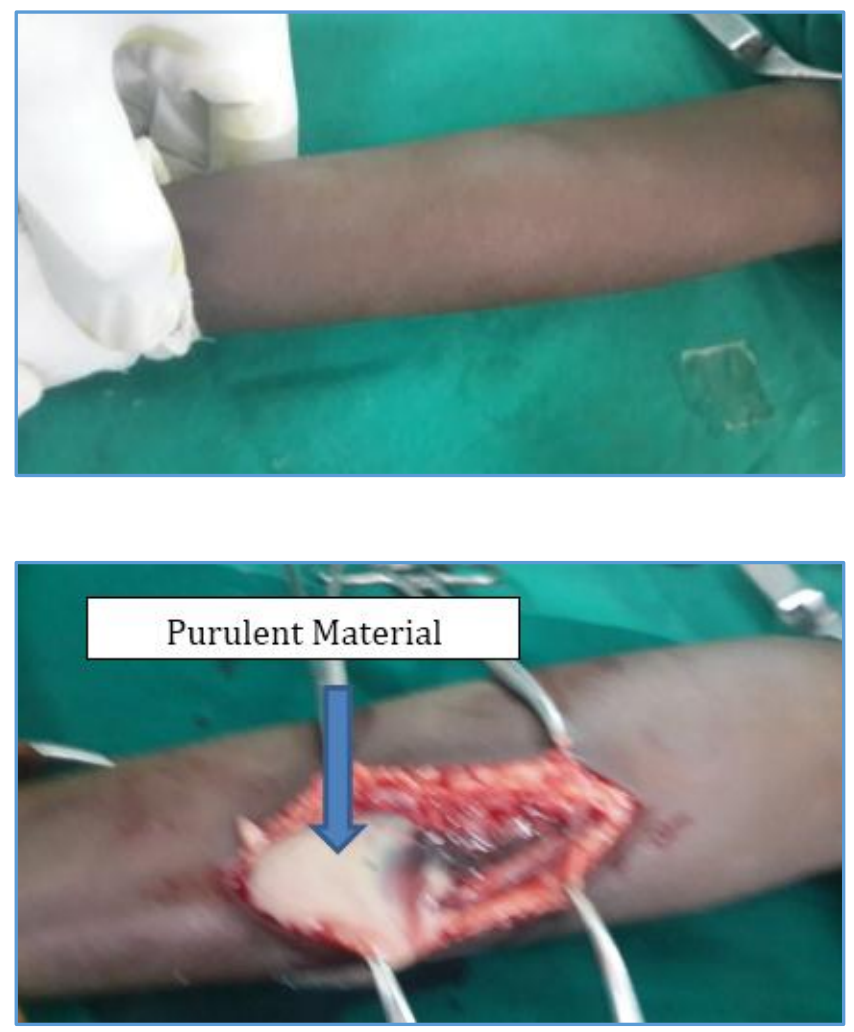

\section{Followup Evaluation}

The patient was followed at 3 months and at 6 months. At 3 months followup, the pt. was on ATT and the followup radiograph showed healing lesion and clinically the child had no specific complaints with full range of motion at the adjacent joints. 


\section{Clinical Picture}

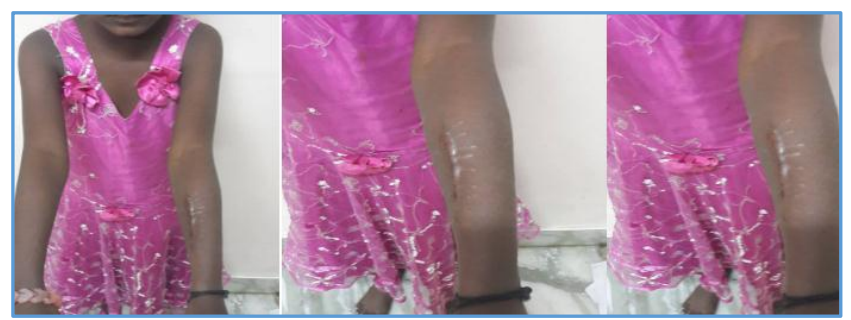

\section{Radiological Picture}

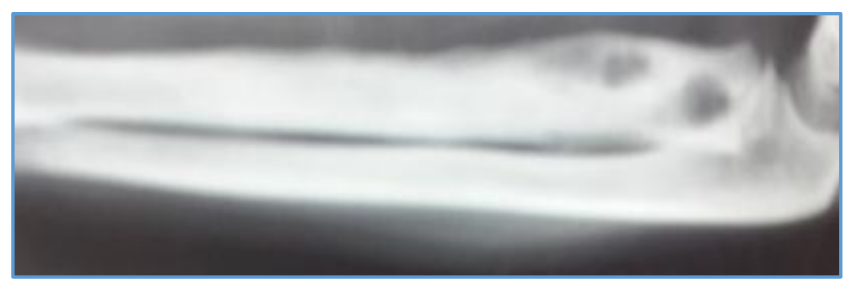

At 6 months followup, the lesion completely healed. Radiologically, the patient finished the whole course of ATT. Clinically, there was no recurrence of swelling or pain. The child had full range of motion of adjacent joints.

\section{Clinical Picture}

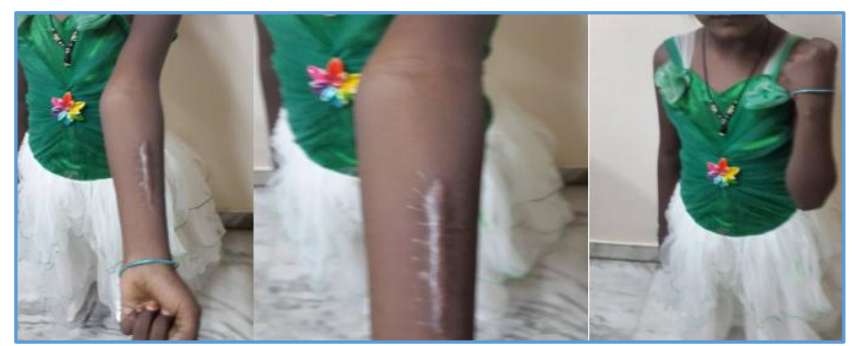

\section{Radiological Picture}

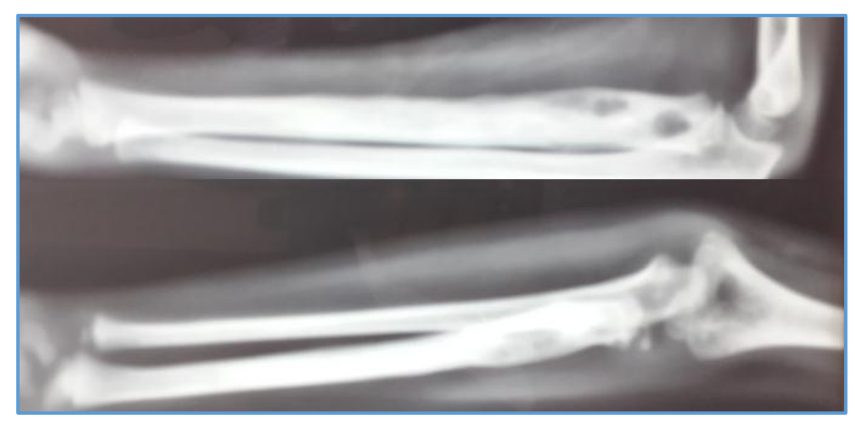

\section{Case II}

Case 2

Synovial Biopsy was suggestive of Tuberculous Granuloma.

- Patient was registered and was started on Category I AntiTubercular Therapy.

\section{Followup Evaluation}

The patient was followed up clinically and radiologically at 3 months and at 6 months. At 3 months followup, the pt. was on ATT and the followup radiograph showed healing lesion and clinically the patient had no specific complaints with full range of motion at the knee joint and adjacent joints as well.
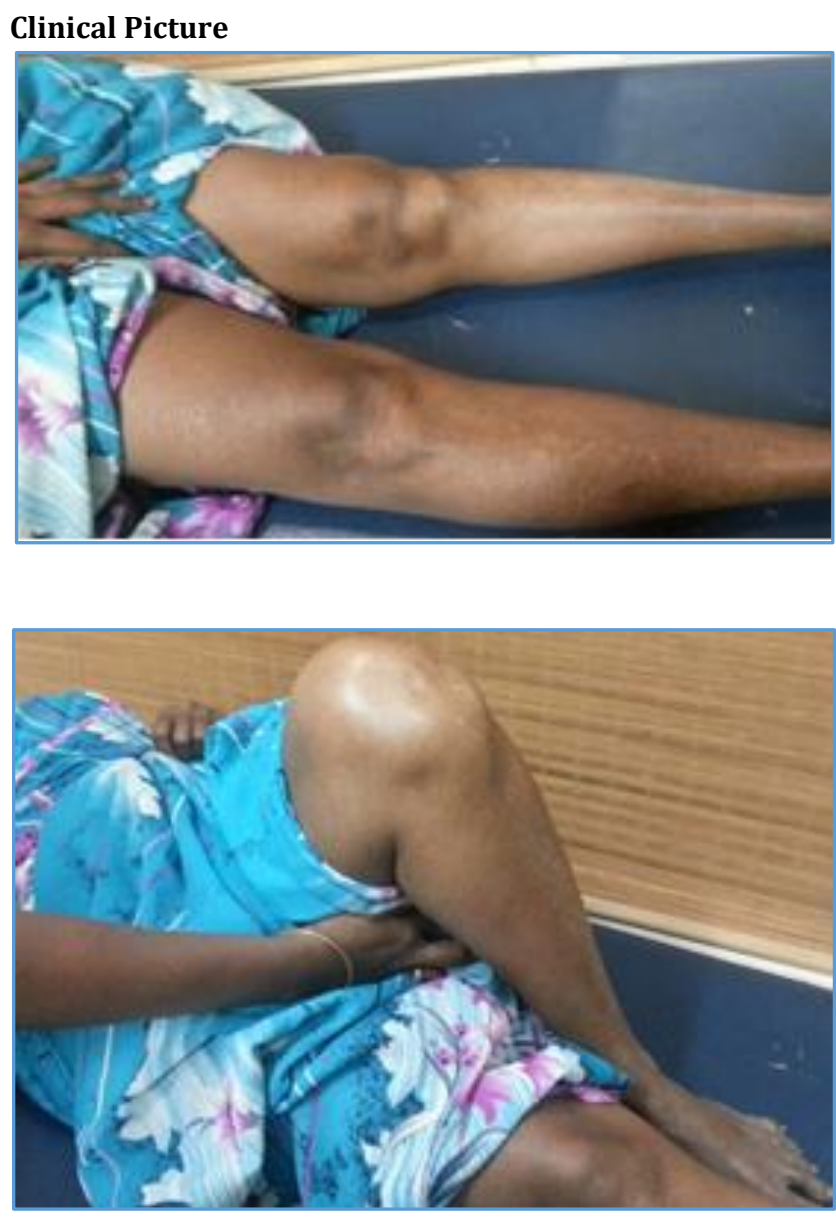

\section{Radiological Picture}

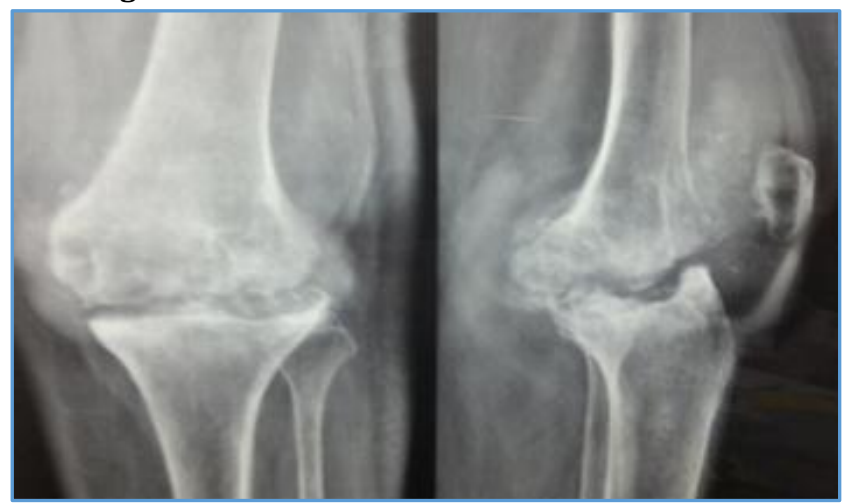

At 6 months followup, the lesion completely healed. Radiologically, the patient finished the whole course of ATT. Clinically, there was no recurrence of swelling or pain. The patient had full range of motion of knee joint as well as adjacent joints. 


\section{Clinical Picture}
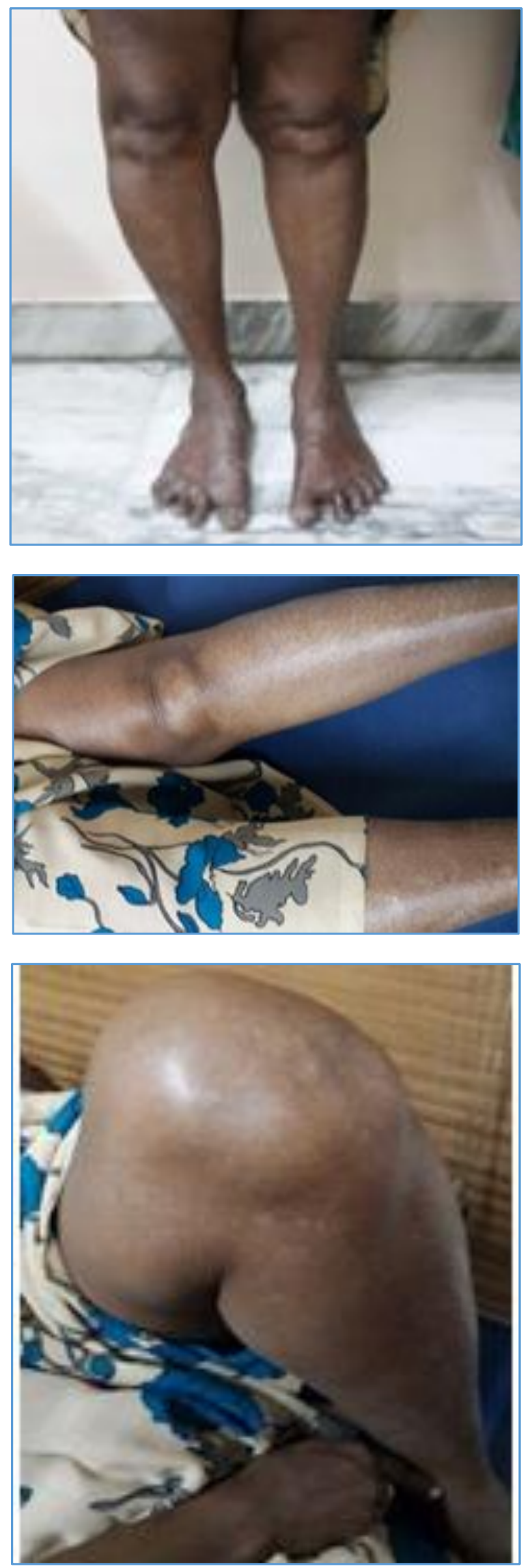

\section{Radiological Picture}
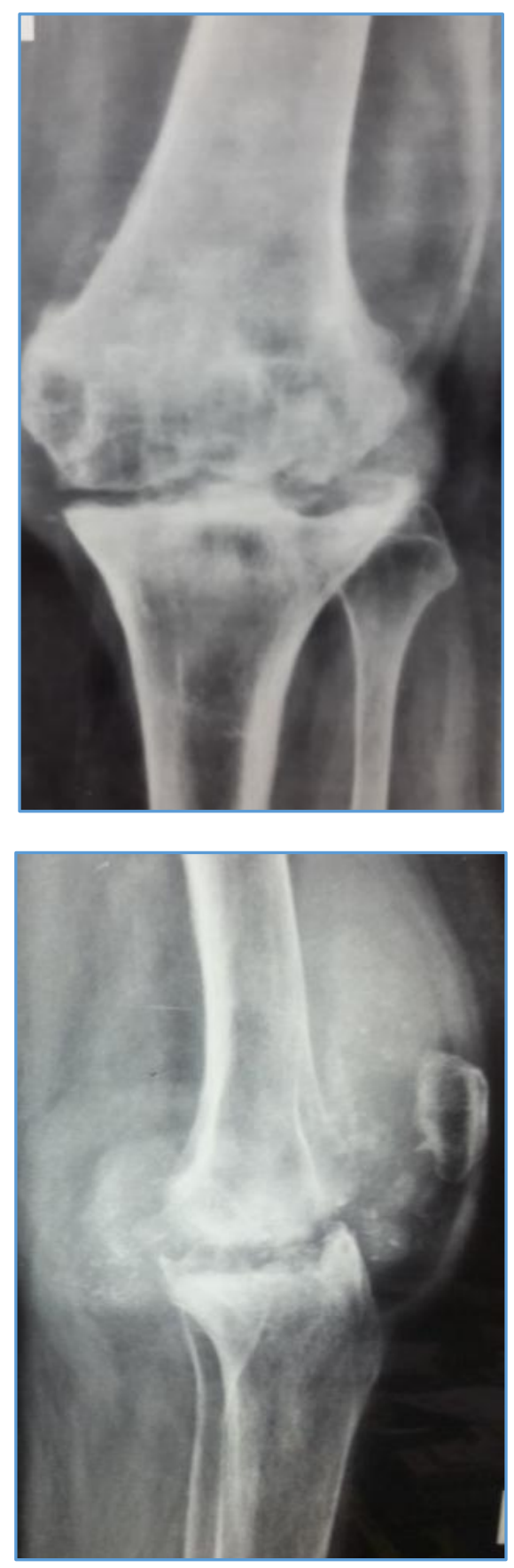

\section{FINAL DIAGNOSIS}

Both the patients included in the above study presented with atypical symptoms suggesting diagnosis other than Tuberculosis; later were biopsy proven Tuberculosis; were treated with Anti-Tubercular Therapy.[9][10] Both patients showed complete healing of the lesion at $6^{\text {th }}$ month followup after completing ATT course with full preservation of joint movements.[11]

- Incidence of Pulmonary TB has grossly reduced over the years.[12]

- Atypical presentations are not uncommon.[13]

- Due to MDR/ XDR TB, emergence especially of skeletal TB with atypical presentations is on rise.[14]

- Diagnosis is difficult and detected only in late stages.[15] 
- Combined approach to clinical tests, radiological and histopathological examination will help in arriving at the appropriate and early diagnosis.[16]

- Anti-Tubercular Therapy is the treatment of choice and surgery indicated only in selected cases.[17]

\section{CONCLUSION}

- Early diagnosis is essential to prevent long-term disability[17] (Availability of Potent Drugs).

- Combined clinical approach and investigations aid in early and accurate diagnosis.[18]

- Anti-Tubercular Therapy is the treatment of choice with surgical intervention needed only in some cases.[19]

\section{REFERENCES}

[1] Marudanayagam A, Gnanadoss JJ. Multifocal skeletal tuberculosis: a report of 3 cases. The Iowa Orthopedic Journal 2006;26:151-3.

[2] Swain B, Misra S, Pattnaik K, et al. Tuberculosis of Calcaneum: a case report. Indian J Tub 2001;48:20910.

[3] Dhillon MS, Sharma S, Gill SS, et al. Tuberculosis bones and joints of the foot: an analysis of 22 cases. Foot Ankle 1993;14(9):505-13.

[4] Dhillon MS, Agarwal S, Prabhakar S, et al. Tuberculosis of the foot: an osteolytic variety. Indian J Orthop 2012;46(2):206-11.

[5] Halit M, Yillm AZ. Multi focal skeletal tuberculosis. South Med J 2004;97(8).

[6] Mittal R, Gupta V, Rastogi S. Tuberculosis of the foot. JBJS 1999;81(6):997-1000.

[7] Moon MS. Tuberculosis of the spine. Controversies and new challenge. Spine (Phila Pa 1976) 1997;22(15): 1791-7.
[8] Valsalan R, Purushothaman R, Raveendran MK, et al. Efficacy of directly observed treatment short course intermittent regimen in spinal tuberculosis. IJO 2012;46(2):138-44.

[9] Tuli SM, Sinha GP. Skeletal tuberculosis "unusual" lesions. IJO 1969;3(1\&2):5-18.

[10] Zahraa J, Johnson D, Lim-Dunham JE, et al. Unusual features of osteoarticular tuberculosis in children. J Pediatr 1996;129(4):597-602.

[11] Lakhkar DL, Yadav M, Soni A, et al. Unusual presentation of shoulder joint tuberculosis: a case report. Ind J Radiol Imag 2006;16(1):23-6.

[12] Opara TN, Gupte CM, Liyanage SH, et al. Tuberculous arthritis of the knee with Staphylococcus superinfection. J Bone Joint Surg (Br) 2007;89(5):6646.

[13] Tuli SM. General principles of osteoarticular tuberculosis. Clin Orthop Relat Res 2002;398:11-9.

[14] Ambedkar YK. Working group on tuberculosis, Indian Academy of Pediatrics. Consensus statement on childhood tuberculosis. Ind Pediatr 2010;47(1):41-55.

[15] Tuli SM. Tuberculosis of the Skeletal System. $1^{\text {st }}$ edn. New Delhi: Jaypee Brothers Medical Publishers 1997.

[16] Watts HG, Lifeso RM. Current concepts review. Tuberculosis of bones and joints. J Bone Joint Surg (Am) 1996;78(2):288-98.

[17] Arora A. Basic science of host immunity in osteoarticular tuberculosis - a clinical study. Ind J Orthop 2006;40(1):1-15.

[18] Teklali Y, El Alami ZF, El Madhi T, et al. Peripheral osteoarticular tuberculosis in children: 106 casereports. Joint Bone Spine 2003;70(4):282-6.

[19] Martini M, Adjrad A, Boudjemaa A. Tuberculous osteomyelitis. A review of 125 cases. Int Orthop 1986;10(3):201-7. 